\title{
Investment of Czech Institutional Sectors in the Business Cycle ${ }^{\#}$
}

\author{
Lukáš Kučera*
}

\section{Introduction}

Investment forms vital part of gross domestic product (GDP) regarding expenditure side. Its growth increases demand and subsequently pushes on GDP growth. Fall in investment, on the contrary, decreases demand and thus, pushes on GDP drop. Investment fluctuations highly contribute to GDP fluctuations and therefore, they intensively contribute to business cycle. In the long term, investment raises GDP level from the supply side.

But one has to expect that there is not one-way relationship only. As investment forms GDP and contributes to business cycle, current state of business cycle affects investment as well. Some of theoretical models such as Investment accelerator model or Financial accelerator model "are based on" this fact.

The aim of this paper was to confirm, that investment on the macroeconomic level is highly pro-cyclical and volatile component of GDP, which, however, cannot be perceived as homogenous. Analysis of investment on the macroeconomic level and investment on institutional sectors level, both within a business cycle, was the tool to achieve it. Although there is not a tested causality between GDP cycle and investment cycle, we also try to interpret the findings in a way that investment cycle is influenced by GDP cycle, which is in line with models mentioned above.

\# This article is based on the conference contribution presented within The 15th Annual Conference of the Faculty of Finance and Accounting, University of Economics, Prague on the 6th June 2014 and whose abstract was published in the Collection of Abstracts - Kučera (2014). The article is processed as an output of a research project Financial and Economic Cycle registered by Internal Grant Agency of University of Economics in Prague under the registration number F1/5/2014.

Ing. et Ing. Lukáš Kučera - PhD. Student; Department of Monetary Theory and Policy, Faculty of Finance and Accounting, University of Economics, Prague, W. Churchill Sq. 4, 13067 Prague, Czech Republic; <kucera-lukas@email.cz>. 


\section{Empirical and Theoretical Background}

\subsection{Literature Overview}

An analysis of investment on the macroeconomic level with respect to Czech data was dealt with by Hloušek (2006). He comes to a conclusion that investment cycle is pro-cyclical and volatile component of GDP cycle. He concludes also that the relationship between investment cycle and GDP cycle is strongest when investment cycle lags by one quarter.

Sedláček (2006) analysed relationship between investment and GDP in the Czech economy as well. He worked with unfiltered series, not with cyclical components only. Paper comes to a conclusion that investment is a pro-cyclical component of GDP and, that relationship between time series is strongest in the same period. Although Sedláček (2006) partly mentioned specifics of investment of institutional sectors as well, he did not calculate strength of its relationship to GDP.

\subsection{Investment Accelerator Model}

Investment accelerator model belongs to basic models, which try to link movements in investment to movements in performance. Since the model deals with one representative firm, it can be labelled as microeconomic model. We start with the definition used by Parker (2009). Model expects that it is convenient for a firm to dispose of stable capital stock in relation to its production. Model operates in the short run which allows us to expect that the capital productivity is stable. Therefore, if the firm faces fluctuations in production, it proportionally adjusts capital stocks. It thus holds that:

$$
\begin{aligned}
\mathrm{CS}_{\mathrm{t}}^{*}=\sigma \mathrm{Y}_{\mathrm{t}} & \\
\text { where } \quad \mathrm{CS}_{\mathrm{t}}^{*} & =\text { optimal capital stock, } \\
\sigma & =\text { relation of capital stock to production, } \\
\mathrm{Y}_{\mathrm{t}} & =\text { production. }
\end{aligned}
$$

Model assumes that the firm invests in period $t$ in order to ensure optimal capital stock in period $t+1$. Parker (2009) simplifies the reality in the way that he does not take into account an existence of capital depreciation. If the representative firm disposed of optimal capital stock in the period $\mathrm{t}$, investment in $\mathrm{t}$ should be as following:

$$
\mathrm{I}_{\mathrm{t}}=\mathrm{CS}_{\mathrm{t}+1}^{*}-\mathrm{CS}_{\mathrm{t}}^{*}
$$


When we substitute equation (1) into equation (2) we get investment expression in period $t$ as the function of expected change in production:

$$
\mathrm{I}_{\mathrm{t}}=\sigma \mathrm{Y}_{\mathrm{t}+1}^{\mathrm{e}}-\sigma \mathrm{Y}_{\mathrm{t}}=\sigma\left(\mathrm{Y}_{\mathrm{t}+1}^{\mathrm{e}}-\mathrm{Y}_{\mathrm{t}}\right)
$$

According to Parker (2009), the equation (3) can be simplified in the sense that the firm expects the same change in production as it observed between period $t-1$ and $t$. This is nothing else than the form of adaptive expectations. Equation (3) changes into:

$$
\mathrm{I}_{\mathrm{t}}=\sigma\left(\mathrm{Y}_{\mathrm{t}}-\mathrm{Y}_{\mathrm{t}-1}\right)
$$

The impact of change in production on investment activity is determined by parameter $\sigma$. If $\sigma$ is lower/higher than one, investment in period $t$ is lower/higher than positive change in production. As Parker (2009) concludes, the ratio of capital stock to production in most of countries is higher than one, in developed countries several times higher than one - therefore, even the small change in production affects investment activity very significantly.

Representative firm invests in period t according to equation (4) if and only if production in period $t$ is higher than production in period $t-1$. If $\sigma$ equals to 3 for example and the firm records the growth in production from level of 100 units in period t- 1 to 110 units in period t, it invests 30 units in period $t$. If the firm will record the growth of production from 110 units in period t to 130 units in the period $t+1$, it will invest 60 units in period $t+1$. If the firm records stagnation, it does not invest. If the firm records the fall in production, investment should be negative according to the model and the capital stock should decrease - Czesaný (2006) states that the fall in demand (that transfers to fall in production) implies that the current capital stock is redundant. It follows from previous that the small change in production has a relatively strong impact on changes in investment activity. Hence, investment variability should be higher than production variability. Investment should move pro-cyclically with respect to production and it should not delay nor forgo to changes in production. Investment should react immediately.

There are two crucial complications with the model as it was presented when we want to use it to explain investment movements in relation to business cycle. First, model operates with firms only. Even if we assume that every firm in the economy behaves according to the model, there are other subjects creating investment. Therefore, model can be smoothly used on institutional sectors level. On the macroeconomic level, however, one has to bear in mind that households or government 
will behave differently. Second, representative firm in the model reacts to its level of production. Since we need to link the movements in investment to business cycle, which is characterized, by GDP movements, we need to assume that production movements are connected to gross value added (GVA) movements on the firm level. This, however, has economic basics - firms will not have any incentives to invest if production rises and GVA does not.

\subsection{Financial Accelerator Model}

The basic principle of financial accelerator model, which was dealt with by Bernanke et al. (1996), lies in the interaction of the real economy and credit markets. According to authors, small exogenous real shock is able to change situation in the credit markets significantly. Changes in the credit markets, nevertheless, are transferred back to the real economy and the original shock is amplified.

Bernanke et al. (1996) construct the model regarding the following assumptions. First, external financial sources demanded by subjectsclients are more expensive than internal financial sources. This occurs due to the existence of asymmetric information when the credit institutions do not have all the information about clients and their projects. Bernanke et al. (1996) note, that the exception may be a situation when all provided funds are covered by collateral. Second assumption is, that the premium, which is paid by the clients to credit institutions (in excess of the cost of internal financial sources), is inversely related to their net worth. Premium rises/falls when clients' net worth falls/rises. Third, in case of decline/increase in clients' net worth, premium rises/falls but also the need for external financial sources rises/falls. This according to Bernanke et al. (1996) leads to fall/growth in production and expenditures. It should be noted that this model is basically a modification of well-known experience that production and expenditures react inversely to changes in the interest rate.

Let's use the model to link investment movements to business cycle. First, there is an exogenous real shock. If the shock is positive/negative (GDP rises/falls), net worth of clients rises/falls. This leads to lower/higher need for external financial sources, which are, however, due to fall/growth in premium cheaper/more expensive. This has a positive/negative impact on investment activity. It arises from the financial accelerator model that growth/fall in GDP is connected to growth/fall in investment. It can be also assumed that investment 
responds to changes in GDP in some delay. Since the model does not distinguish between clients-subjects, there is no complication with the interpretation on the macroeconomic level.

\section{Methodology}

Three steps must be done before the analysis. First, term "investment" must be clearly defined. Second, institutional sectors and their motivation to invest have to be presented. Third, data source and data adjustment must be discussed.

\subsection{Investment}

Gross domestic product is defined according to ESA 1995 (CZSO, 2000) as the following sum:

$$
\mathrm{GDP}=\mathrm{FCE}+\mathrm{GCF}+\mathrm{B}
$$

where $\mathrm{FCE}=$ final consumption expenditure,

$\mathrm{GCF}=$ gross capital formation,

$$
\mathrm{B}=\text { external balance (export }- \text { import). }
$$

GCF is considered as investment in broader view. If demand for GCF rises and GDP in the same time does not change, it has a negative impact on other expenditure items - either FCE decreases, and therefore living conditions of households worsens ${ }^{1}$ (GCF growth is financed from higher savings), or B worsens (export of investment goods must fall or import of investment goods must rise). This, however, happens only in the short run.

Higher GCF, that displaced FCE or B, increases GDP dynamics and GDP level in the future. If the growth of GCF and fall in FCE or in B on the expenditure side takes place in the short run, higher growth of GDP and higher GDP level on the supply side takes place in the medium and long run. This "extra value" can be used for additional development, for consumption or for export. Although GCF belongs to other expenditure items such as FCE, export and import, it is obvious, that it has specific ability to affect future level of economy performance.

1 Goods and services purchased using final consumption expenditure belong solely to households. Collective consumption expenditure which is paid by government in order to ensure goods and services consumed by whole society is the only exception. 
However, GCF is not a homogenous item and it must be decomposed further. It breaks according to ESA 1995 (CZSO, 2000) into:

$$
\begin{aligned}
\mathrm{GCF}=\mathrm{GFCF} & +\mathrm{CHII}+\mathrm{NAoV} \\
\text { where } \mathrm{GFCF} & =\text { gross fixed capital formation, } \\
\mathrm{CHII} & =\text { change in inventories, } \\
\mathrm{NAoV} & =\text { net acquisition of valuables. }
\end{aligned}
$$

GFCF includes net investment into tangible fixed assets (e. g. production facilities, dwellings, machines, transport equipment etc.), net investment into intangible fixed assets (e. g. software) and addition to the value of non-produced non-financial assets (investment which increases value of land) - see for example Sixta (2007). All components are in gross expression, which means that depreciation is included. CHII equals to growth of inventory level in the economy if positive and to decrease of inventory level if negative. It consists of material and semi-finished products, unfinished products, finished goods and goods for resale. NAoV equals to net expenditure for valuable items and arts.

It follows from GCF structure that GFCF only can be the source of long-term growth, and therefore, labelled as true investment. Higher or lower level of inventories will not affect GDP growth or its future level, the same applies for higher or lower NAoV. From this point, only GFCF is labelled as investment ${ }^{2}$.

\subsection{Institutional Sectors}

GFCF on the macroeconomic level is formed by GFCF on institutional sectors level. ESA 1995 (CZSO, 2000) divides the national economy into following sectors: non-financial corporations, financial corporations, government institutions, households and non-profit institutions serving to households (hereinafter marked as non-profit institutions). Non-residents do not participate on GFCF.

Primary goal of non-financial corporations is to make profits and to maximize the market value of the institution. To do this, these institutions use investment that increases their production capacity and therefore, GVA volume that is divided among individual factors of production. Part of GVA, which belongs to corporations, or owners respectively (gross

2 Still, one has to bear in mind that not all types of GFCF have to fully initiate economic growth. E. g. dwellings investment has definitely lower production capacity than investment into production facilities or machines. 
operating surplus), corresponds to profit which growth increases market value of the institution. Generally, non-financial corporations have a quite strong tendency to invest. We can say that the same is applied - but in much lower extent - for financial corporations as well, which invest primarily into buildings or technical equipment.

Government institutions have different reason to invest. Their aim is not to make profits but rather to ensure the functioning of the state. More specifically, long-term economy development, support of other institutional sectors or minimizing the cyclical fluctuations of the economy belongs to primary goals that may be achieved through investment activity adjustments.

The objective of households is primarily to ensure the highest possible standard of living that can be identified with the level of consumption. Even though the households sector creates investment. Since the household sector consists in addition to classical households-consumers of the self-employed, GFCF of these subjects has to be distinguished. GFCF of households equals according to Hronová et al. (2009, pp. 158) to "investment of small entrepreneurs into their production capacities and investment of classical households that are only net purchases of apartments and houses". Households-consumers, therefore, invest primarily in order to improve the level of living conditions, self-employed persons in order to make profits, which means that their motivation to invest is similar to motivation of firms.

Non-profit institutions are the last one and the smallest one of all institutional sectors. Their goal is to support the households sector. It can be said that non-profit institutions invest in order to retain their activity in the future.

\subsection{Data}

Not seasonally adjusted quarterly values at current prices, which are published within national accounts by Czech Statistical Office (CZSO, 2014), are the source of data. Time series are bounded by $1^{\text {st }}$ quarter 1999 and by $1^{\text {st }}$ quarter 2014 . GFCF of the national economy is at disposal apart from data at current prices even at constant prices (prices of year 2005), GFCF of individual institutional sectors is not. However, due to the intertemporal comparability, one should work with data at constant prices.

With respect to the fact that relevant price indexes (deflators), which can be used for conversion of data at current prices into data at constant 
prices, do not exist for GFCF of individual institutional sectors, simplification is used. Price index of GFCF of the national economy although we know that prices of investment assets developed differently across institutional sectors (for example prices of housing vs. prices of machinery) - is used for the conversion.

Only deflator that identifies price change on the year basis (change in prices of aggregate in one quarter against the same quarter of the previous year) is available within not seasonally adjusted data. This deflator, however, cannot be used for transformation of data at current prices into data at constant prices (that is prices of one year). Relevant price index is, therefore, calculated as the ratio of GFCF at current prices and the GFCF at prices of year 2005. This price index determinates the change in prices of GFCF in particular quarter against the average prices of year 2005. Acquired price index is then used to convert GFCF of all individual institutional sectors at current prices into prices of year 2005 .

Since GFCF of all institutional sectors is deflated using the same price index, which corresponds to price changes in GFCF of the national economy, non-additivity problem does not arise (more information about non-additivity problem for example in Fischer, 2005 or Široký, 2004). Therefore, sum of GFCF of all institutional sectors at prices of 2005 equals to GFCF of the national economy at prices of 2005.

$\mathrm{Cycle}^{3}$, that is subsequently analysed, is separated from time series of GFCF and GDP at prices of 2005. Focusing strictly on the cyclical component enables analysis of relationships between time series, which reflect short-term fluctuations only, particularly as a result of the business cycle. First, trend is removed from all time series. Method or filter respectively that was designed by Hodrick and Prescott (1997) is used for this purpose. Hodrick and Prescott (1997) state that any time series can be decomposed into trend component (growth component) and cyclical component according to:

$$
\mathrm{y}_{\mathrm{t}}=\mathrm{g}_{\mathrm{t}}+\mathrm{c}_{\mathrm{t}}
$$

Where $y_{t}=$ original time series,

$\mathrm{g}_{\mathrm{t}}=$ trend (growth) component,

$\mathrm{c}_{\mathrm{t}}=$ cyclical component .

Cyclical component is according to Hodrick and Prescott (1997) a deviation from trend component, its long-term average is approaching to

3 Process used in this paper is similar to Kučera (2012). 
zero and when one wants to separate cyclical component from trend component, he/she minimizes following argument:

$$
\left\{\sum_{\mathrm{t}=1}^{\mathrm{T}} \mathrm{c}_{\mathrm{t}}^{2}+\lambda \sum_{\mathrm{t}=1}^{\mathrm{T}}\left[\left(\mathrm{g}_{\mathrm{t}}-\mathrm{g}_{\mathrm{t}-1}\right)-\left(\mathrm{g}_{\mathrm{t}-1}-\mathrm{g}_{\mathrm{t}-2}\right)\right]^{2}\right\}
$$

Specific setting of $\lambda$ parametr, which defines smoothness of acquired trend, is crucial according to authors. If $\lambda$ gets higher, acquired trend component gets smoother and volatility is more captured within cyclical component. If $\lambda$ decreases, acquired trend component becomes more fluctuating and cyclical component, on the other hand, gets smoother. Hodrick and Prescott (1997) use $\lambda$ which value equals to 1600 for the separation of cycle from trend in the context of quarterly data, therefore, the same value of parameter is chosen to split the components in this paper.

When one removes trend component from original time series using the method of Hodrick and Prescott (1997), not only pure cyclical component but also seasonality and random component remains in the series. These components with short-term period of repetition are necessary to be removed from the series. Pure cycle, that is the part with the longest period of repetition, must on the contrary remain it the series. Butterworth filter, that is capable to separate components, is used (for more information see for example Pollock, 2000).

\section{Analysis}

\subsection{National Economy}

Development of original time series of GDP and GFCF of the national economy (at prices of 2005, not seasonally adjusted) and acquired cyclical components are at disposal in figures 1 and 2 .

It arises from graphical analysis already that GDP cycle and GFCF cycle are connected. While GDP cycle was decreasing till mid-2004, since the second part of the year there was a significant growth of its volume. Beginning of this period was probably determined, among other factors, by accession of the Czech Republic to the European Union. This event had a positive effect on Czech economy performance from the side of foreign trade. Growth of demand for Czech products from abroad, supported by positive economic development in Europe, however, did not increased GDP only, it led to growth of investment activity in the Czech Republic as well. Firms invested due to growth of business opportunities and a vision of further positive economic development, households 
increased their investment due to improvement in their revenue situation, which enabled them to purchase own housing more intensively. This, nevertheless, occurred with a lag. GFCF cycle started to increase in 2006.

Decline in the cyclical component of GDP and GFCF in 2008 and the beginning of 2009 is linked to each other quite strongly. Drop in export led to unfavourable expectations of firms regarding future economic development. This was subsequently transferred to a significant reduction of investment activity in the Czech economy. Lower investment reduced demand for product that manifested in lower GDP. Investment cycle and GDP cycle dropped simultaneously.

Fig. 1: GDP and its cycle (at prices of year 2005, in bil. CZK)

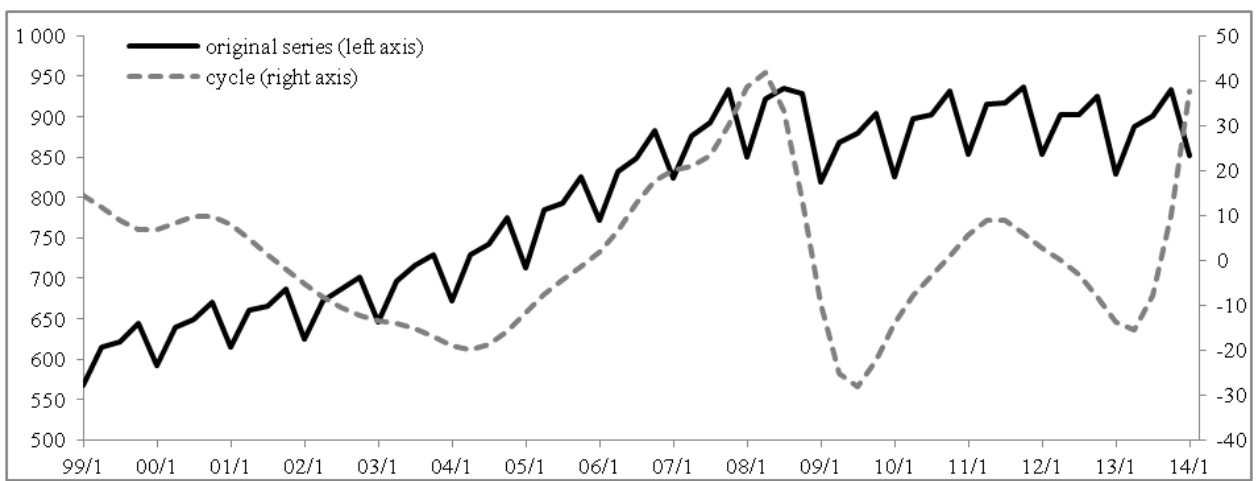

Source: CZSO (2014), own calculations.

Fig. 2: GFCF of the national economy and its cycle (at prices of year 2005, in bil. CZK)

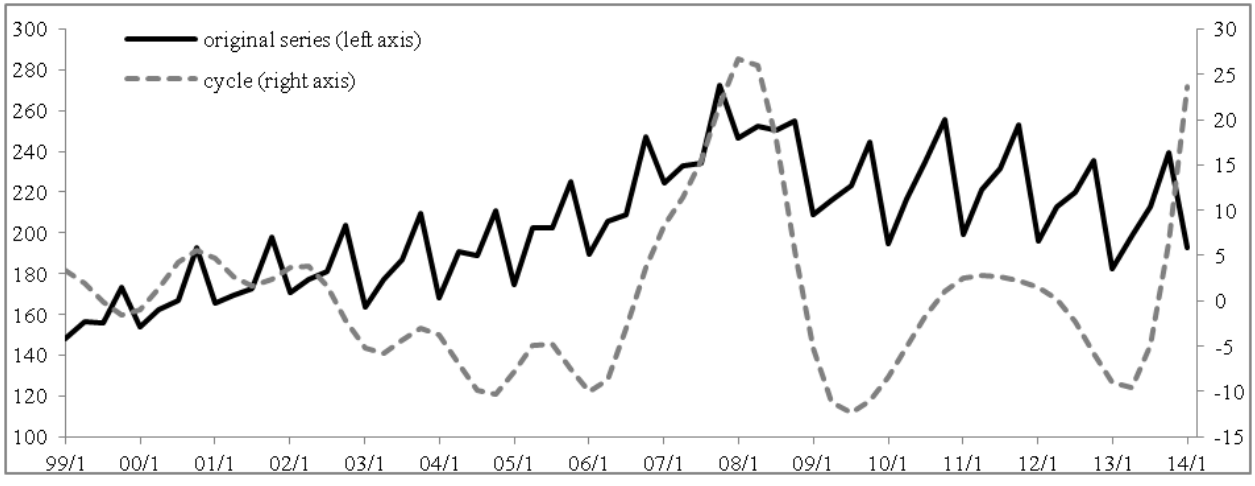

Source: CZSO (2014), own calculations. 
Relationship between cyclical components is quantified using the correlation coefficient. The value amounted for the cyclical component of GFCF and GDP cycle of 0.89 , which indicates a very strong positive relationship. It applies, therefore, that the growth/fall in GFCF cycle is accompanied by growth/fall in GDP cycle and vice versa. Correlation coefficient between GFCF cycle and GDP cycle decreases to 0.76 when GFCF cycle precedes in front of GDP cycle by one quarter. When one shifts time series of GFCF cycle behind the GDP cycle by one quarter on the contrary (investment lags by one quarter), coefficient of correlation decreases to 0.80 . The value of the correlation coefficient with respect to the time delay between GFCF cycle and GDP cycle is evident from the figure number 3. Although there is still pro-cyclical relationship between GFCF cycle and GDP cycle when one shifts one time series in front of/behind each other, it decreases. Identified pro-cyclicality of investment with respect to GDP is consistent with theoretical models discussed, the strongest relationship in the same period with investment accelerator model only. Result of pro-cyclicality of investment with respect to GDP is also in line with an assumption.

\section{Fig. 3: Coefficient of correlation between cyclical component of GFCF of the national economy and cyclical component of GDP with respect to shift in time series*}

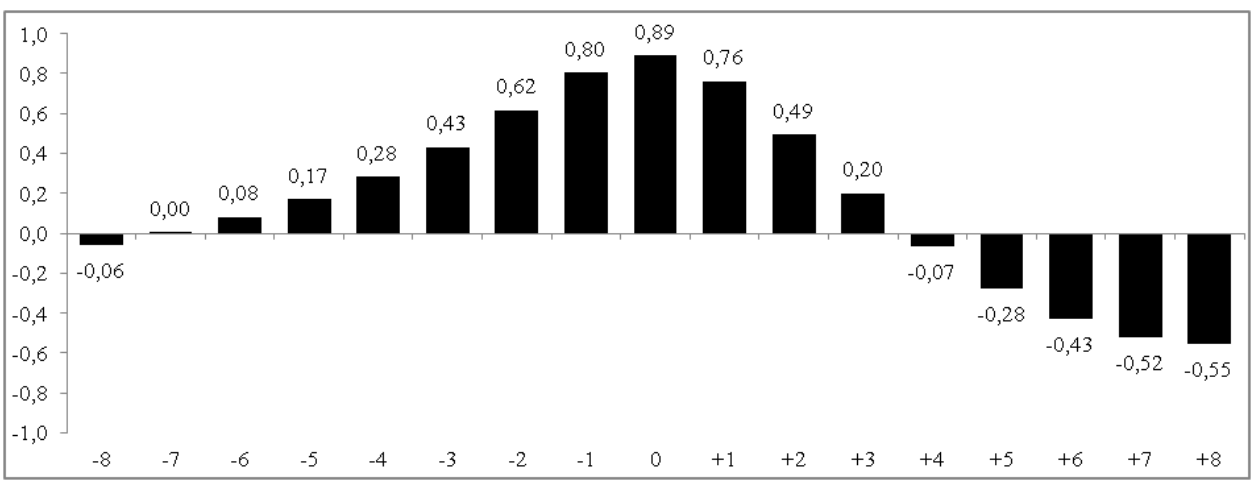

Source: CZSO (2014), own calculations.

*Positive/negative values indicate preceding/lagging of GFCF cycle (lagging/preceding of GDP cycle respectively).

The variability of time series is described using the coefficient of variation $^{4}$. The coefficient of variation of GDP cycle equals to 12.7 of

4 The coefficient of variation eliminates in contrast to absolute indicators of variability (e. g. variance, standard deviation) effect of different levels of time series. The 
GFCF cycle reaches 18.5. Variability of cyclical component of GFCF is therefore higher than variability of cyclical component of GDP. Identified higher volatility of GFCF cycle compared to GDP cycle is consistent with investment accelerator model. Financial accelerator model does not mention what the variability relation should be. Identified higher volatility of GFCF cycle compared to GDP cycle confirms an assumption of high variability of GFCF cycle.

With respect to the fact that the absolute level of fluctuation of GDP cycle is significantly higher than fluctuation of GFCF cycle (GDP cycle exhibits higher amplitudes) ${ }^{5}$, it is obvious, that other expenditure items of GDP take part on volatility of GDP in business cycle as well. Volatility of GDP in the business cycle is not, therefore, a result of investment volatility only.

\subsection{Institutional sectors}

Developments of original time series of GFCF of individual sectors (at prices of 2005, not seasonally adjusted) and acquired cyclical components are at disposal in figures $4-8$.

Fig. 4: GFCF of non-financial corp. and its cycle (at prices of year 2005, in bil. CZK)

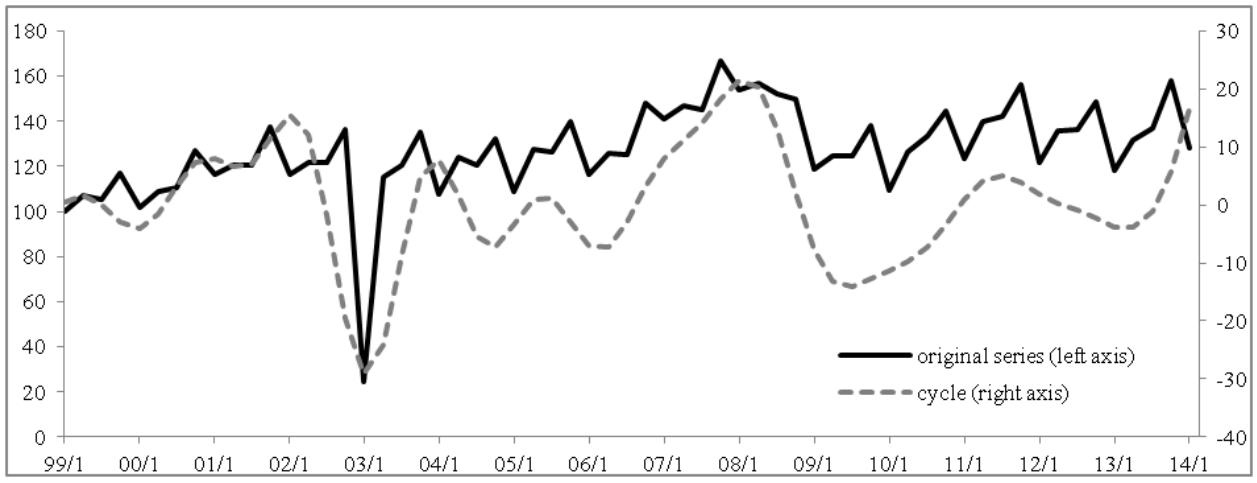

Source: CZSO (2014), own calculations.

coefficient of variation, therefore, allows us to compare variability across different time series.

5 Standard deviation of GDP cycle $=16.0$ billion CZK; standard deviation of GFCF cycle $=8.9$ billion CZK. 
Fig. 5: GFCF of financial corporations and its cycle (at prices of year 2005, in bil. CZK)

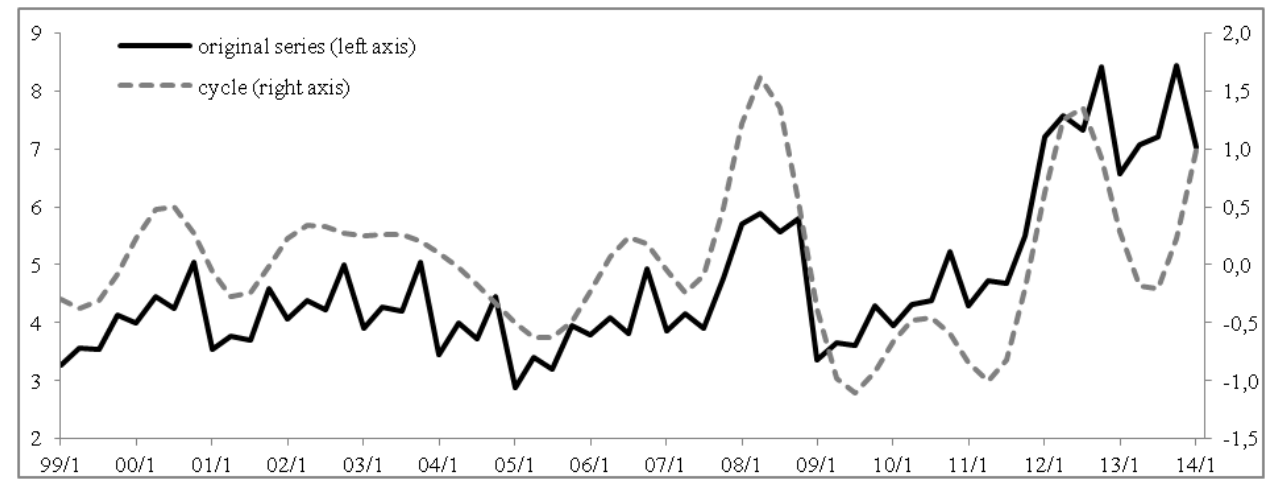

Source: CZSO (2014), own calculations.

Fig. 6: GFCF of government inst. and its cycle (at prices of year 2005, in bil. CZK)

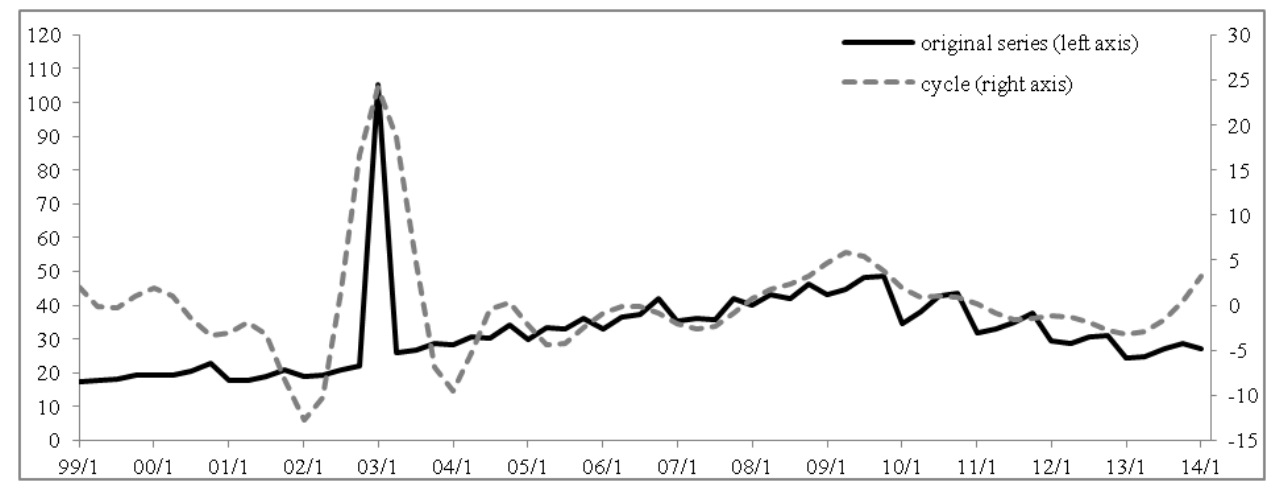

Source: CZSO (2014), own calculations. 
Fig. 7: GFCF of households and its cycle (at prices of year 2005, in bil. CZK)

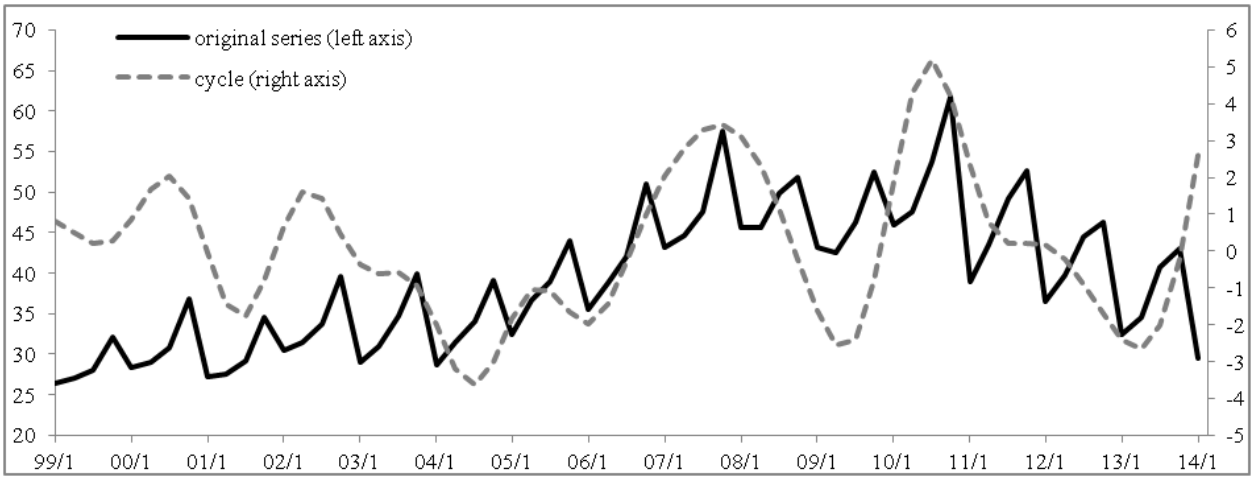

Source: CZSO (2014), own calculations.

Fig. 8: GFCF of non-profit inst. and its cycle (at prices of year 2005, in mil. CZK)

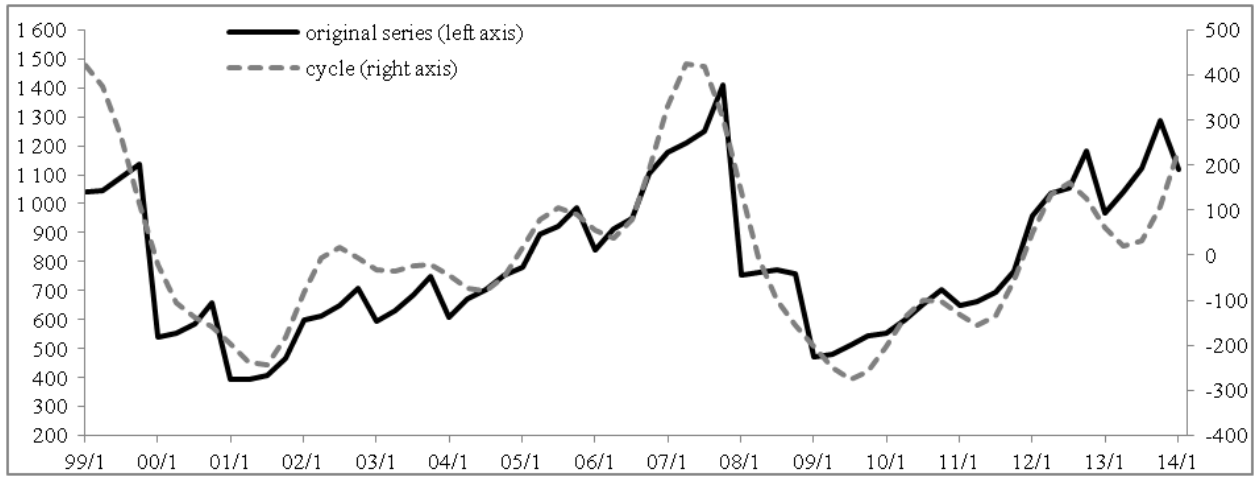

Source: CZSO (2014), own calculations.

Relationship between cyclical components of GFCF of individual institutional sectors and cyclical component of GDP is again quantified using the correlation coefficient. These are for easy reference at disposal in table number 1 . 


\section{Tab. 1: Coefficient of correlation between cyclical component of GFCF of the national economy (institutional sectors respectively) and cyclical component of GDP}

\begin{tabular}{|c|c|c|c|c|c|}
\hline $\begin{array}{c}\text { National } \\
\text { economy }\end{array}$ & $\begin{array}{c}\text { Non- } \\
\text { financial } \\
\text { corporations }\end{array}$ & $\begin{array}{c}\text { Financial } \\
\text { corporations }\end{array}$ & $\begin{array}{c}\text { Government } \\
\text { institutions }\end{array}$ & Households & $\begin{array}{c}\text { Non-profit } \\
\text { institutions } \\
\text { serving to } \\
\text { households }\end{array}$ \\
\hline 0.89 & 0.69 & 0.47 & -0.09 & 0.60 & 0.47 \\
\hline
\end{tabular}

Source: CZSO (2014), own calculations.

The strongest relationship between GFCF cycle and GDP cycle was found out regarding non-financial corporations (0.69). This is, even though, significantly less than in the case of the cyclical component of GFCF of the national economy and the GDP cycle (0.89). It seems that combination of relationship of cyclical component of GFCF of individual institutional sectors and GDP cycle participates on high coefficient of correlation between cyclical component of GFCF of the national economy and GDP cycle, rather than strong pro-cyclicality of investment of one particular sector.

Pro-cyclical development of investment with respect to GDP was found out also in case of households (0.60), financial corporations (0.47) and non-profit institutions (0.47). Only correlation coefficient between cyclical component of GFCF of government institutions and GDP cycle is negative (-0.09). It arises from these findings that investment of government institutions is slightly anti-cyclical.

If cyclical component of GFCF of non-financial corporations precedes in front of GDP cycle by one quarter, correlation coefficient falls to 0.60. If cyclical component of GFCF of non-financial corporations lags by one quarter, correlation coefficient declines to 0.64 . It is evident, therefore, that the strongest relationship between these time series exists in the same period. It applies that the growth/decline in cyclical component of GFCF of non-financial corporations is associated with growth/decline in GDP cycle in the same period. The same applies for households $(0.60)$.

Different conclusion, however, applies for other sectors. The strongest correlation coefficient with respect to non-profit institutions was found out when investment cycle precedes in front of GDP cycle by three quarters (0.56). The highest coefficient of correlation with respect to government institutions - negative one - was found out when investment cycle precedes in front of GDP cycle by four quarters $(-0.23)$. One of 
possible interpretations of this evidence is that non-profit institutions and government institutions are partly forward-looking and adjust cyclical volume of its investment in some advance. Correlation coefficient between cyclical component of GFCF of financial corporations and GDP cycle is the highest when investment cycle lags behind GDP cycle by one quarter (0.49). It may be assumed with respect to evidence that sector of financial corporations is more cautious when making investment decisions and waits for actually observable changes in GDP cycle.

Out of all institutional sectors, GFCF of government institutions fluctuate the most in the business cycle - coefficient of variation reaches - 5 792.0. GFCF of government institutions is followed with respect to variability by GFCF of financial corporations (30.1), GFCF of nonfinancial corporations (29.9) and GFCF of non-profit institutions (27.5). If coefficient of variation of GDP cycle equals to 12.7 , it applies, that investment activity of all above-mentioned sectors is more volatile in the business cycle than GDP.

The lowest coefficient of variation was found out with respect to cyclical component of GFCF of households (15.8). This fact may indicate that investment of households is quite sticky in the business cycle. As mentioned, investment into housing takes part in investment of this sector significantly. Since this type of investment is investment for a lifetime, households - when deciding whether to invest or not - probably take into account the phase of business cycle only to a limited extend. Low variability of cyclical component of GFCF of households is the opposite of high variability of cyclical component of GFCF of government institutions. It may suggest, among other possible interpretations, that sector of government institutions reacts to actual phase of business cycle and adjusts the volume of its GFCF significantly. It tampers cyclical investment when GDP cycle grows, it increases cyclical investment when GDP cycle falls (this arises from negative correlation coefficient). An effort to moderate business cycle fluctuations may stand behind this evidence. Second possible interpretation of high variability of cyclical component of GFCF of government institutions may be the effect of political cycle. In this case, government institutions do not react to actual phase of business cycle but meet the objectives, which were specified by contemporary elected political authorities. Fact that there was found a negative coefficient of correlation between cyclical component of GFCF of government institutions and GDP cycle would not have any interpretation in this case, however. 
It is necessary to mention, that although variability of cyclical component of GFCF of all institutional sectors in case of coefficient of variation is higher than variability of GDP cycle, absolute cyclical fluctuations of investment of individual institutional sectors are lower than fluctuations of GDP cycle ${ }^{6}$.

It is apparent from the analysis of cyclical components of GFCF of individual institutional sectors that every sector adjusts its investment in the business cycle differently. Therefore, cyclical investment on the macroeconomic level is heterogeneous. An assumption was proved.

\section{Conclusion}

It was proved that investment (gross fixed capital formation) is very pro-cyclical component of demand. Correlation coefficient between investment cycle on the macroeconomic level (gross fixed capital formation of the national economy) and GDP cycle equals to 0.89 . This is true for quarterly data since $1^{\text {st }}$ quarter 1999 till $1^{\text {st }}$ quarter 2014 in case of the Czech Republic. Relationship between investment cycle and GDP cycle is strongest in the same period - coefficient of correlation gets lower when one time series lags behind the second one. It was also expected that the variability of investment in the business cycle is high. This assumption with respect to the fact that coefficient of variation of investment cycle is higher than coefficient of variation of GDP cycle was also proved.

Investment on the macroeconomic level is heterogeneous. It is determined by investment of individual institutional sectors, which develops very differently. It suggests that specific factors stand behind investment of institutional sectors and its development.

Pro-cyclical development of investment with respect to GDP was found out regarding all sectors except government institutions. The strongest positive coefficient of correlation between GDP cycle and cyclical component of investment of financial corporations was found out when investment cycle lags by one quarter, of non-profit institutions

6 Standard deviation of GDP cycle $=16.0$ billion CZK; standard deviation of cyclical component of GFCF of non-financial corporations $=9.9$ billion $\mathrm{CZK}$; standard deviation of cyclical component of GFCF of financial corporations $=0.6$ billion $\mathrm{CZK}$; standard deviation of cyclical component of GFCF of government institutions $=5.8$ billion $\mathrm{CZK}$; standard deviation of cyclical component of GFCF of households $=2.0$ billion $\mathrm{CZK}$; standard deviation of cyclical component of GFCF of non-profit institutions $=0.2$ billion $\mathrm{CZK}$. 
serving to households when investment cycle precedes by three quarters. Coefficient of correlation between GDP cycle and investment cycle of non-financial corporations is strongest in the same period, the same is applied for households. Government institutions, with respect to sign of correlation coefficient, is the only exception - correlation coefficient between investment cycle and GDP cycle equals to negative value, relationship is strongest when investment cycle precedes in front of GDP cycle by four quarters.

Variability of investment cycle of all institutional sectors with respect to coefficient of variation is higher than variability of GDP cycle. Among them, variability of cyclical component of investment of households is lowest. This fact may indicate that households take into account the business cycle when making investment decisions in a limited way, and therefore, their investment is in the business cycle compared to other sectors relatively sticky. Opposed to this, variability of investment cycle of government institutions is not very high only, but the highest of all institutional sectors. This finding, in combination with negative coefficient of correlation between investment cycle and GDP cycle, may indicate some effort of government institutions to stimulate demand using investment in order to smooth business cycle, or, on the other hand, may indicate the effect of political cycle.

Limitations of findings, that were presented, are based on the methodology that was chosen and are unambiguous. Connection between variables, i.e. investment cycle and GDP cycle, is measured by simple correlation coefficient and findings are interpreted in a way that investment cycle is influenced by GDP cycle. However, this causality may not be proved when one would test it by using more advanced methods. Therefore, further research should be performed. For example, VAR model describing short-term relationship between variables or error correction model covering long-term relationship between variables may be constructed. Furthermore, one may be interested in relationship between cyclical component of investment into housing, other buildings and structures, machinery and equipment or transport equipment and GDP cycle. This analysis may provide some more - not only interesting but also important - findings that help us to understand the movement of investment in the business cycle. 


\section{References}

Bernanke, B. - Gertler, M. - Gilchrist, S. (1996): The Financial Accelerator and the Flight to Quality. The Review of Economics and Statistics, 1996, vol. 78, no. 1, pp. 1-15.

Czech Statistical Office (2000): Evropský systém účtů ESA 1995 (European System of Accounts ESA 1995). [on-line], Prague, CZSO, 2000, [cited $1^{\text {th }}$ July 2014], <apl.czso.cz/nufile/ESA95_cz.pdf>.

Czech Statistical Office (2014): Hrubý domácí produkt - Časové rady ukazatelì čtvrtletnich účtů (Gross Domestic Product - Time Series of Quarterly Accounts). [on-line], Prague, CZSO, 2014, [cited $9^{\text {th }}$ July 2014], <http://www.czso.cz/csu/redakce.nsf/i/hdp_cr>.

Czesaný, S. (2006): Hospodářský cyklus: teorie, monitorování, analýza, prognóza (Business Cycle: Theory, Monitoring, Analysis, Prognosis). Prague, Linde, 2006.

Fischer, J. (2005): Problémy měření HDP (Problems of GDP Measurement). In Loužek, M. (ed.): Měříme správně HDP? (Do We Measure GDP Correctly?). Prague, CEP, pp. 11-20, 2005.

Hloušek, M. (2006): Czech Business Cycle Stylized Facts. Working Paper, no. 10/2006. Brno, Research Centre for Competitiveness of Czech Economy, 2006.

Hodrick, R. J. - Prescott, E. C. (1997): Postwar U.S. Business Cycles: An Empirical Investigation. Journal of Money, Credit and Banking, 1997, vol. 29, no. 1, pp. 1-16.

Hronová, S. - Fischer, J. - Hindls, R. - Sixta, J. (2009): Národní účetnictví. Nástroj popisu globální ekonomiky (National Accounts. A Tool for Describing the Global Economy). Prague, C. H. Beck, 2009.

Kučera, L. (2012): Změna stavu zásob a hospodářský cyklus (Change in Inventories and the Business Cycle). In Procházka, D. (ed.): The $13^{\text {th }}$ Annual Doctoral Conference of the Faculty of Finance and Accounting, University of Economics, Prague. Prague, Oeconomica, pp. 435-446, 2012.

Kučera, L. (2014): Formování národohospodářských investic $v$ hospodárském cyklu (Forming of Aggregate Investment in The Business Cycle). In Procházka, D. (ed.): The $15^{\text {th }}$ Annual Conference of the Faculty of Finance and Accounting, University of Economics, Prague. Prague, Oeconomica, pp. 32, 2014.

Parker, J. (2009): Economics 314 Coursebook. Theories of Investment Expenditures (Chapter 15). [on-line], Portland, Reed College, [cited $10^{\text {th }}$ 
Kučera, L.: Investment of Czech Institutional Sectors in the Business Cycle.

July 2014], <http://academic.reed.edu/economics/course_pages/314_s09/ Coursebook/Ch15.pdf $>$.

Pollock, D. S. G. (2000): Trend estimation and de-trending via rational square-wave filters. Journal of Econometrics, 2000, vol. 99, no. 2, pp. 317-334.

Sedláček, P. (2006): Analýza investičního cyklu (Investment Cycle Analysis). Statistika, 2006, vol. 86, no. 6, pp. 477-496.

Sixta, J. (2007): Odhady spotřeby fixniho kapitálu (Estimations of Consumption of Fixed Capital). Statistika, 2007, vol. 87, no. 2, pp. 156163.

Široký, M. (2004): Řetězení stálých cen v národnich účtech (Constant Prices Chaining in the National Accounts). [on-line, presentation], Prague, CZSO, [cited $8^{\text {th }}$ July 2014], <www.mfcr.cz/cs/oministerstvu/vzdelavani/seminare/2004/rok-2004-podzimni-seminar6690>. 


\title{
Investment of Czech Institutional Sectors in the Business Cycle
}

\begin{abstract}
Paper deals with the analysis of investment in the business cycle. Analysis is based on available quarterly data for the Czech Republic since $1^{\text {st }}$ quarter 1999 till $1^{\text {st }}$ quarter 2014. It concludes that investment on the macroeconomic level is highly pro-cyclical component of demand, which fluctuates in the business cycle more than GDP. Investment of individual institutional sectors, which together forms investment of the national economy, behaves in the business cycle highly differentiated. Investment of households, for example, develops the same way as GDP and its volatility is quite low. Investment of government institutions, on the contrary, is strongly volatile, and in addition, develops slightly anticyclically. It applies therefore, that cyclical component of investment of the national economy is very heterogeneous.
\end{abstract}

Key words: Investment; Business cycle; Institutional sectors.

JEL classification: E22, E32 